\title{
PENGOPTIMALAN BADAN USAHA MILIK NAGARI PARAMBAHAN MELALUI PEMBENTUKAN BANK SAMPAH
}

\author{
Nizwardi jalinus ${ }^{1 *}$, Rian Surenda ${ }^{2)}$, Yaumal Arbi ${ }^{3)}$ \\ 1,2,3 Universitas Negeri Padang, J1 Hamka, Padang, Indonesia. \\ nizwardi@unp.ac.id*; riansurenda@fpp.unp.ac.id; yaumalarbi@ft.unp.ac.id
}

\begin{abstract}
ABSTRAK
Pemerintahan Nagari Parambahan mendirikan Badan Usaha Milik Nagari (BumNag) yang bergerak dibidang daur ulang sampah plastik sebagai upaya untuk menumbuhkan kembali ekonomi masyarakat akibat wabah covid-19. Pengoptimalan ini berupa pembentukan bank sampah. Bank sampah sebagai wadah penyaluran dan pengolahan sampah dan dapat memberikan tambahan pendapatan bagi masyarakat nagari. Pengabdian ini bertujuan agar masyarakat nagari Parambahan mengenal keberadaan bank sampah dengan memberikan sosialisasi, pelatihan teknis pengolahan sampah agar bernilai ekonomis, pembentukan dan pelaksanaan sistem bank sampah. Sosialisasi diberikan berupa penyuluhan, poster dan spanduk. Pelatihan teknis pengolahan sampah plastik dengan menggunakan mesin pencacah yang telah diberikan. Pelatihan pembuatan kompos dengan alat komposter. Diharapkan dengan pembentukan bank sampah ini dapat menyerap tenaga kerja dari masyarakat dan meningkatkan ekonomi masyarakat nagari Parambahan.
\end{abstract}

Kata kunci: BumNag, Plastik, Bank sampah, Nagari Parambahan

\section{ABSTRACT}

The Nagari Parambahan government established a Nagari-Owned Enterprise (BumNag) which is engaged in the recycling of plastic waste as an effort to regenerate the community's economy due to the COVID-19 outbreak. This optimization is in the form of forming a waste bank. The waste bank is a place for distributing and processing waste and can provide additional income for the Nagari community. This service aims to make the Nagari Parambahan community aware of the existence of a waste bank by providing socialization, technical training on waste processing so that it has economic value, establishing and implementing a waste bank system. Socialization was given in the form of counseling, posters, and banners. Technical training on processing plastic waste using a shredder has been provided. Composting training with a composter. It is hoped that the formation of this waste bank can absorb labor from the community and improve the economy of the Parambahan village community.

Keywords: BumNag, Plastic, Garbage bank, Nagari Parambahan

Diunggah November 2021, direvisi: Desember 2021, diterima: Desember 2021, dipublikasi: 31 Desember 2021 Copyright (c) 2021 Nizwardi jalinus, Rian Surenda, Yaumal Arbi

This is an open access article under the CC-BY license

\section{PENDAHULUAN}

Salah satu solusi dalam mengelola sampah adalah dengan mendirikan Bank Sampah yang akan bertanggung jawab dalam mereduksi dan melakukan pengelolaan sampah plastik (Syafrudin et al., 2019). Pemerintah mengeluarkan pertaturan tentang Pedoman Pelaksanaan Reduce, Reuse, dan Recycle melalui Peraturan Menteri Negara Lingkungan Hidup Republik Indonesia Nomor 13 Tahun 2012. Peraturan ini menjelaskan bagaimana mekanisme program bank sampah yang ideal dan komprehensif. Peraturan ini juga menjelaskan bahwa pendirian bank sampah sangat didukung oleh pemerintah. 
Bank sampah secara umum memiliki kesamaan dengan bank komersial yang melakukan kegiatan tabung-menabung, namun tabungan yang diberikan pada pihak bank berupa sampah yang telah ditentukan jenisnya (Saputro et al., 2015). Setiap sampah akan ditimbang dan akan dilakukan pencatatan berat dan akan dicatat pada buku tabungan nasabah. Berat dari sampah yang ditabungkan akan dikonversikan dalam bentuk rupiah sesuaidengan harga yang ditentukan oleh bank. Bank sampah yang berjalan efektif dapat mengurangi jumlah timbulan limbah padat yang ditransportasikan ke landfill (Suryani, 2014).

Pembentukan bank sampah di Nagari Parambahan dilakukan sebagai salah satu upaya pengoptimalan badan usaha milik nagari yang selama ini telah bergerak dibidang pengelolaan sampah.. Nagari Parambahan memiliki potensi daur ulang sampah plastik sebesar 1,74 $\mathrm{m}^{3} /$ hari (Arbi et al., 2019). Maka dengan pembentukan bank sampah dapat menyerap lapangan kerja dari masyarakat, miningkatkan ekonomi m,asyarakat yang menjadi nasabah bank sampah dan mereduksi sampah yang akan dikirim ke tempat pemrosesan akhir (Suwerda et al., 2019).

\section{METODE}

Kegiatan ini dilaksanakan mulai Bulan Oktober 2021 oleh Tim Pengabdian Universitas Negeri Padang. Tahap awal Tim pengabdaian melakukan survey ke Nagari Parambahan, Survey dilakukan untuk menganalisis situasi agar pembentukan bank sampah dapat berjalan dengan lancar. Pada kegiatan survey juga dilakukan diskusi dengan pihak nagari dan BumNag yang ditujuk oleh Walinagari sebagai pengelola bank sampah. Diskusi ini menyepakati beberapa hal yang berhubungan dengan [pembentukan bank sampah, yaitu:

1. Sosialisasi

Sosialisasi ini bertujuan agar masyarakat Nagari Parambahan memiliki pengetahuan dasar mengenai bank sampah yang meliputi manfaat, tatacara pengelolan dan system menabung pada bank sampah. Masyarakat sebagai calon nasabah dari bank sampah harus diberikan pemahaman yang psitif terhadap pembentukan bank sampah dan manfaat yang akan mereka peroleh agar kegiatan ini dapat berjalan dengan sukses.

2. Pelatihan Teknis

Pelatihan teknis diberikan kepada calon pekerja pada bank sampah, meliputi pekerjaan pemilahan, penimbangan, pencatatan, pengelohan sampah plastik menggunakan mesin pencacah yang telah diberikan, pengolahan sampah organik menjadi kompos.

3. Pemantauan dan evaluasi

Pemantauan dan evakausi diperlukan agar sistem yang digunakan dapat berjalan sehingga manfaat dari pendirian bank sampah ini dapat dirasakan oleh masyarakat Nagari Parambahan. Hasil dari pemantauan dan evaluasi juga berguna untuk pengembangan sistem kearah yang lebih baik.

\section{HASIL DAN PEMBAHASAN}

Dari rangkaian kegiatan pengabdian dalam pembentukan bank sampah ini didapatkan hasil sebagai berikut:

\section{Sosialisasi}

Kegitan sosialisasi ini dilakukan secara bertahap. Pada tahap pertama sosialisasi diberikan kepada calon pengurus bank sampah yang telah ditunjuk oleh walinagari. Bumnag Salona sebagai penelola bank sampah nigari parambahan diberkali dengan buku saku bank sampah yang disusun oleh tim pengabdian. Tahap kedua sosialisasi ditujukan kepada masyarakat nigari sebagai calon nasabah bank sampah, sosialisasi juga dilakukan dengan menempelkan beberapa poster yang mengajak masyarakat agar mensuksekan program nagari dan berperan sarta aktif dalam menabung pada bank sampah.

Materi sosialisasi meliputi pengertian sampah, pembagian jenis-jenis sampah yang dapat ditabung dibank sampah, pemilahan sampah dan proses pembentukan bank sampah. Dookumentasi kegiatan dapat dilihat pada gambar 1 . 


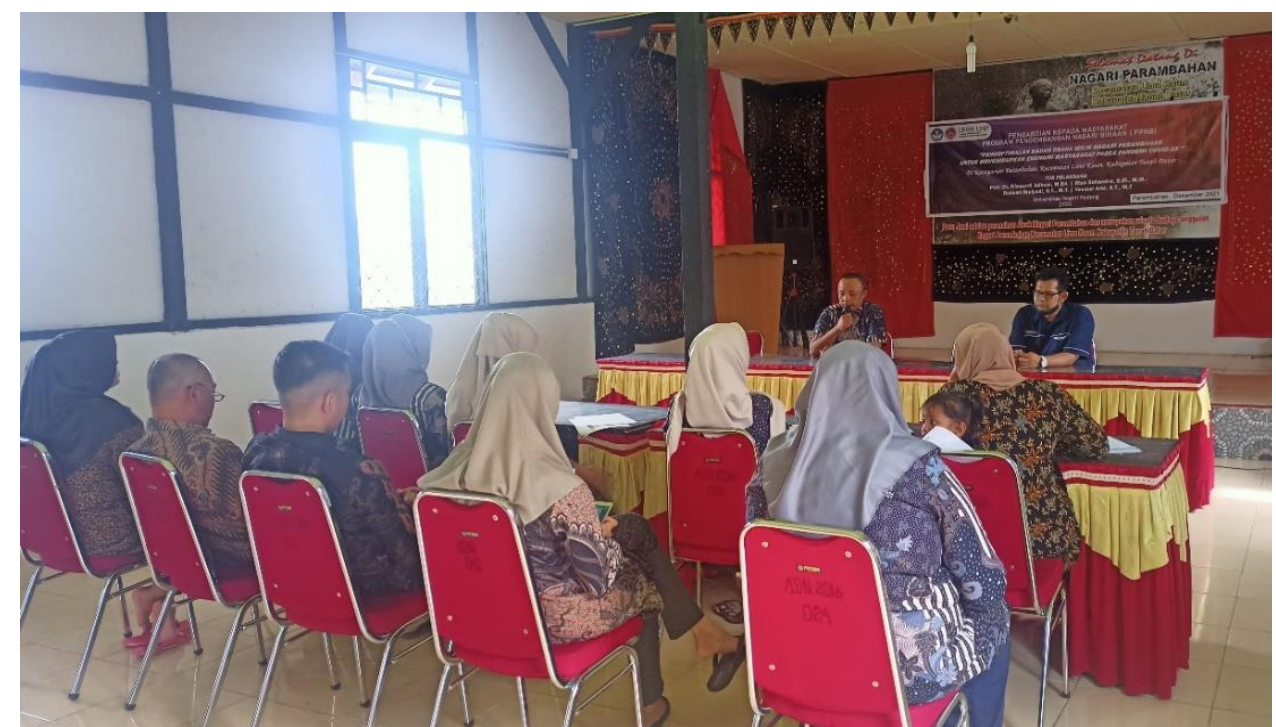

Gambar 1. Sosialisasi pemberntukan bank sampah kepada calon pengelola

\section{Pelatihan Teknis}

Bank sampah Nagari Parambahan yang diberinama Bank Sampah Salona, akan menerima sampah plastik, besi dan sampah organik sebagai materi yang dapat ditabung oleh nasabahnya. Maka dari itu untuk pengelolan sampah plastik diberikan pelatihan yang meliputi pemilahan sampah plastik berdasarkan jenis plastik, pencucian plastik, pencacahan plastik mengunakan mesin pencacah. Untuk sampah besi Cuma dilakukan penimbangan dan pencatatan, sedangkan untuk sampah organik dilakukan pelatihan pengomposan menggunakan komposter aerob.

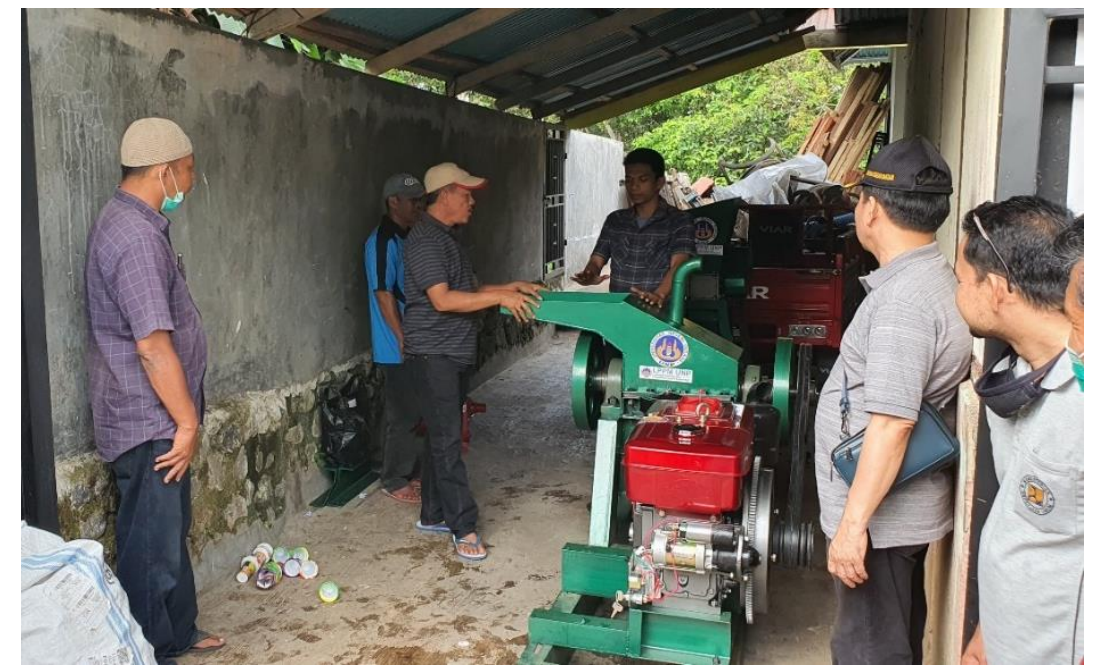

Gambar 2. Pelatihan teknis pencacah plastik

\section{Pemantauan dan Evaluasi}

Proses ini akan dilaksanakan setelah bank sampah berjalan pada bulan ke 3 dan ke 6, dengan melakukan pemantauan dan evaluasi terhadapa bank sampah ini diharapkan dapat memberikan masukan yang positif terhadapa perkembangan bank sampah dan timpengabdian dapat mengukur apakah bank sampah nagari Parambahan bermanfaat bagi peningkatan ekonomi masyarakat nagari. 


\section{KESIMPULAN}

Pemanfaat dan pengelolaan sampah organik dan nonorganik dinagari parambahan dikelola oleh bank sampah Salona. Masyarakat nagari parambahan yang menjadi nasabah bank sampah diharapkan dapat menerima manfaat yang positif dari pembentukan bank sampah ini. Bank sampah ini menyerap tenaga kerja yang berasal dari masyakat nagari dan dapat meningkatkan kebersihan dan menjadi salah satu wadah untuk meningkatkan ekonomi masyarakat.

\section{DAFTAR PUSTAKA}

Arbi, Y., Syaiful, A., Arifin, R., Yandra, M., Siregar, R. L., Tri, I., \& Ningrum, A. (2019). Kajian Komposisi, Karakteristik, Dan Potensi Daur Ulang Sampahnagari Parambahan, Tanah Datar. Seminar Nasional Teknologi Dan Pengelolaan Lingkungan Tropis.

Dhokhikah, Y., Trihadiningrum, Y., Sunaryo, S. (2015). Community Participation in Household Solid Waste

Reduction in Surabaya, Indonesia. Resour. Conserv. Recycl. 102, 153-162.

Friedberg, E., Hilderbrand, M.E. (2017), Observing Policy-Making in Indonesia. Singapore: Springer Nature

Singapore Pte Ltd.

Kementerian Lingkungan Hidup Republik Indonesia. (2012). Bank Sampah: Dari Sampah Jadi Rupiah "From Trash To Cash", tersedia di http://www.menlh.go.id/from-trash-to-cashdari-sampah-jadirupiah/, Diakses tanggal 19 November 2021.

Saputro, Y. E., Kismartini, \& Syafrudin. (2015). Pengelolaan Sampah Berbasis Masyarakat Melalui Bank Sampah. Indonesian Journal of Conservation, 4(1), 83-94.

Suryani, A. S. (2014). Peran Bank Sampah Dalam Efektivitas Pengelolaan Sampah(Studi Kasus Bank Sampah Malang). Jurnal Aspirasi , 5(1), 71-84. http://www.tempo.co/read/news/2012/04/15/063397147/

Suwerda, B., Hardoyo, S. R., \& Kurniawan, A. (2019). Pengelolaan Bank Sampah Berkelanjutan Di Wilayah Perdesaan Kabupaten Bantul. Jurnal Sains Dan Teknologi Lingkungan, 11(1), 74-86.

Syafrudin, Junaidi, \& Ramadan, B. S. (2019). Inisiasi Pembentukan Bank Sampah Di Rt 03 Rw 03 Kelurahan Gedawang Kota Semarang. Jurnal Pasopati, 1(3), 139-143. http://ejournal3.undip.ac.id/index.php/pasopati

Wijayanti, D.R., Suryani, S. (2015). Waste bank as community-based environmental governance: A lesson learned from Surabaya. Procedia - Soc. Behav. Sci. 184, 171-179.

Wynne, A.L., Nieves, P.M., Vulava, V.M., Qirko, H.N. (2018) Callahan, T.J. A communitybased approach to solid waste management for riverine and coastal resource sustainability in the Philippines. Ocean and Coastal Management, 151(2018): 36-44.

World Bank. (2013). Bank Sampah di Indonesia: Menabung, Mengubah Perilaku,tersedia di https://blogs.worldbank.org/eastasiapacific/id/bank-sampah-di-indonesia-menabung mengubah perilaku,diakses tanggal 24 November 2021 